\title{
Millets across Eurasia: chronology and context of early records of the genera Panicum and Setaria from archaeological sites in the Old World
}

\author{
Harriet V. Hunt • Marc Vander Linden · Xinyi Liu • \\ Giedre Motuzaite-Matuzeviciute $\cdot$ Sue Colledge • \\ Martin K. Jones
}

Received: 31 October 2007/Accepted: 15 August 2008/Published online: 14 October 2008

(C) The Author(s) 2008. This article is published with open access at Springerlink.com

\begin{abstract}
We have collated and reviewed published records of the genera Panicum and Setaria (Poaceae), including the domesticated millets Panicum miliaceum L. (broomcorn millet) and Setaria italica (L.) P. Beauv. (foxtail millet) in pre-5000 cal B.c. sites across the Old World. Details of these sites, which span China, centraleastern Europe including the Caucasus, Iran, Syria and Egypt, are presented with associated calibrated radiocarbon dates. Forty-one sites have records of Panicum (P. miliaceum, $P$. cf. miliaceum, Panicum sp., Panicum type, P. capillare (?) and P. turgidum) and 33 of Setaria (S. italica, S. viridis, S. viridis/verticillata, Setaria sp., Setaria type). We identify problems of taphonomy, identification criteria and reporting, and inference of domesticated/wild and crop/weed status of finds. Both broomcorn and foxtail millet occur in northern China prior to 5000 cal в.C.; P. miliaceum occurs contemporaneously in
\end{abstract}

Communicated by A. Fairbairn.

Electronic supplementary material The online version of this article (doi:10.1007/s00334-008-0187-1) contains supplementary material, which is available to authorized users.

H. V. Hunt $(\bowtie)$

McDonald Institute for Archaeological Research,

University of Cambridge, Downing Street,

Cambridge CB2 3ER, UK

e-mail: hvh22@cam.ac.uk

M. Vander Linden · X. Liu · G. Motuzaite-Matuzeviciute .

M. K. Jones

Department of Archaeology, University of Cambridge,

Downing Street, Cambridge CB2 3DZ, UK

S. Colledge

Institute of Archaeology, University College London,

31-34 Gordon Square, London WC1H OPY, UK
Europe, but its significance is unclear. Further work is needed to resolve the above issues before the status of these taxa in this period can be fully evaluated.

Keywords Millet · Early Neolithic · Eurasia .

Chronology · Archaeobotanical methodology

\section{Introduction}

Two cereals with an unusual geographical pattern in the archaeobotanical record are the temperate Eurasian millets Panicum miliaceum L. (broomcorn, proso or common millet) and Setaria italica (L.) P. Beauv. (foxtail millet). Both species are known from a number of sixth and seventh millennium B.C. sites in the Yellow River valley and other regions of north China; $P$. miliaceum has been reported from approximately contemporary sites in eastern Europe and the Caucasus, while $S$. italica appears in the same broad region later, around the 5th/4th millennium B.C. (Gumelnitsa culture) (Zohary and Hopf 2000; Jones 2004). Neither species has so far been recorded from the intervening central Asian region until the mid2nd millennium B.C., when P. miliaceum is found in the Bronze Age site of Tahirbaj Tepe (Nesbitt 1994). Several hypotheses have been proposed to explain the disjunct distributions of these two millet species: a single domestication in either northern China or eastern Europe followed by rapid spread across the central Asian steppe, or multiple domestications that could either represent two discrete events at either end of the region, or diffuse domestication across the steppe zone as a whole (Jones 2004). A resolution to this uncertainly has significant implications for our understanding of interactions between early farming societies across Eurasia. 
Pan-Eurasian summaries of the archaeobotanical evidence for broomcorn and foxtail millet have previously been published by Marinval (1995), Zohary and Hopf (2000) and Jones (2004). The data for Europe (including the Caucasus) is reviewed in Lisitsyna and Prishchepenko (1977), Lisitsyna (1984), and Wasylikowa et al. (1991), and for China in Underhill (1997), Cohen (1998), Shelach (2000), Lu (2005) and Crawford et al. (2007). To date, however, there has been no comprehensive review of early sites with Panicum and Setaria which provides detailed information on sites, calibrated radiocarbon dates and archaeobotanical finds. Such a review is timely for a number of reasons: first, in both eastern Europe and north China a number of new excavations are taking place in which sediment is being floated for archaeobotanical remains, supported by direct dating of carbonized seeds. Second, a number of database projects are improving the international collation of archaeobotanical and radiocarbon dating information (see Shennan and Steele 2000; Colledge et al. 2004, 2005; Kroll 2005).

Our objective in this paper is to collate and present published records of the genera Panicum and Setaria prior to 5000 cal B.C., with details of sites and radiocarbon dates, as a reference source to enable assessment of the biogeography of these two millet taxa in the context of a unified chronology, and to consider the implications for research into the origins and spread of millet agriculture.

The foci of this review are the two principal Asian millet domesticates, $P$. miliaceum and $S$. italica. The primary archaeobotanical literature, however, records finds of the two genera along a continuum of withingenus identifications. In the case of Panicum, the continuum ranges from 'domesticated $P$. miliaceum' through 'Panicum cf. miliaceum', 'Panicum sp.', 'Panicum ?', through to entirely distinct species (Panicum turgidum, not currently known to have any particularly close relationship to broomcorn millet). A similar spectrum exists for Setaria. This is one of the key factors that currently hinder evaluation of the age and geographical range of domesticated broomcorn and foxtail millet, particularly the former. To avoid the twin pitfalls of either potentially overrepresenting the record of securely identified domesticated forms, or excluding tentative or genus-level identifications that may in fact represent domesticates, we chose to report all finds within each genus, with their original identifications. Although this does result in the inclusion of some entirely different species, for example in North Africa, that are most unlikely to be related to the domestication history of the Asian millets, such an 'inclusive' strategy has the advantage of clear boundaries to the data set, and a transparency not easily achieved through attempting to fully subdivide each intrageneric continuum of attempted identifications.

\section{Methodology and results}

We have sought to collate all published records of Panicum and Setaria prior to 5000 cal B.C. This band of time, which encompasses early phases of food production across the area under review, is necessarily arbitrary, but we consider this circumscription to be more useful than for example 'Neolithic sites', since the Neolithic is defined differently in different parts of the world.

For the reasons outlined above, we have included any cited taxon within these two genera. We have not attempted to re-evaluate identifications based on morphological criteria. However, we have assessed the context of and grounds for each identification in terms of preservation type, nomenclature, and chronology.

For Europe and southwest Asia, we have drawn extensively on the databases compiled by Colledge et al. (2004, 2005), Shennan and Conolly (2007) and Kroll (1996, 1997, 1998, 1999, 2000, 2001, 2005). The latter also provides information from beyond this region. For sites in the northern Black Sea region and the Caucasus, we have worked from Lisitsyna and Prishchepenko (1977), Lisitsyna (1984), Wasylikowa et al. (1991), Kotova (2003) and references therein, in addition to Helmut Kroll's database.

For China, a number of English- and Chinese-language references (Crawford 1992; Underhill 1997; Shelach 2000; Liu et al. 2004a; Lu 2005; Crawford et al. 2007; Lee et al. 2007) provide information on sites with millet. We have consulted the primary excavation reports for details of most of these sites, relying on secondary literature where these were not accessible.

Radiocarbon dates were calibrated using OxCal 4.0 (Bronk Ramsey 2001). We report confidence intervals to $2 \sigma$. Included in the data table (Table 1) are all sites with at least one date whose earliest boundary falls before $5000 \mathrm{cal}$ B.c. Where no radiocarbon dates were available, we have reported available chronological information.

Sites producing Panicum and/or Setaria spp. are mapped in Fig. 1, and their details listed in Table 1. We report a total of 41 sites with Panicum identifications (including $P$. miliaceum and equivalent common names, Panicum cf. miliaceum, Panicum sp., Panicum type, Panicum capillare (?) and $P$. turgidum) and 33 with Setaria (S. italica and equivalent common names, Setaria viridis, $S$. viridis/verticillata, Setaria sp.). These totals include nine sites with taxa in both genera.

Detailed information on radiocarbon dates is given in the Supplementary Information (ESM) (Table 3). 


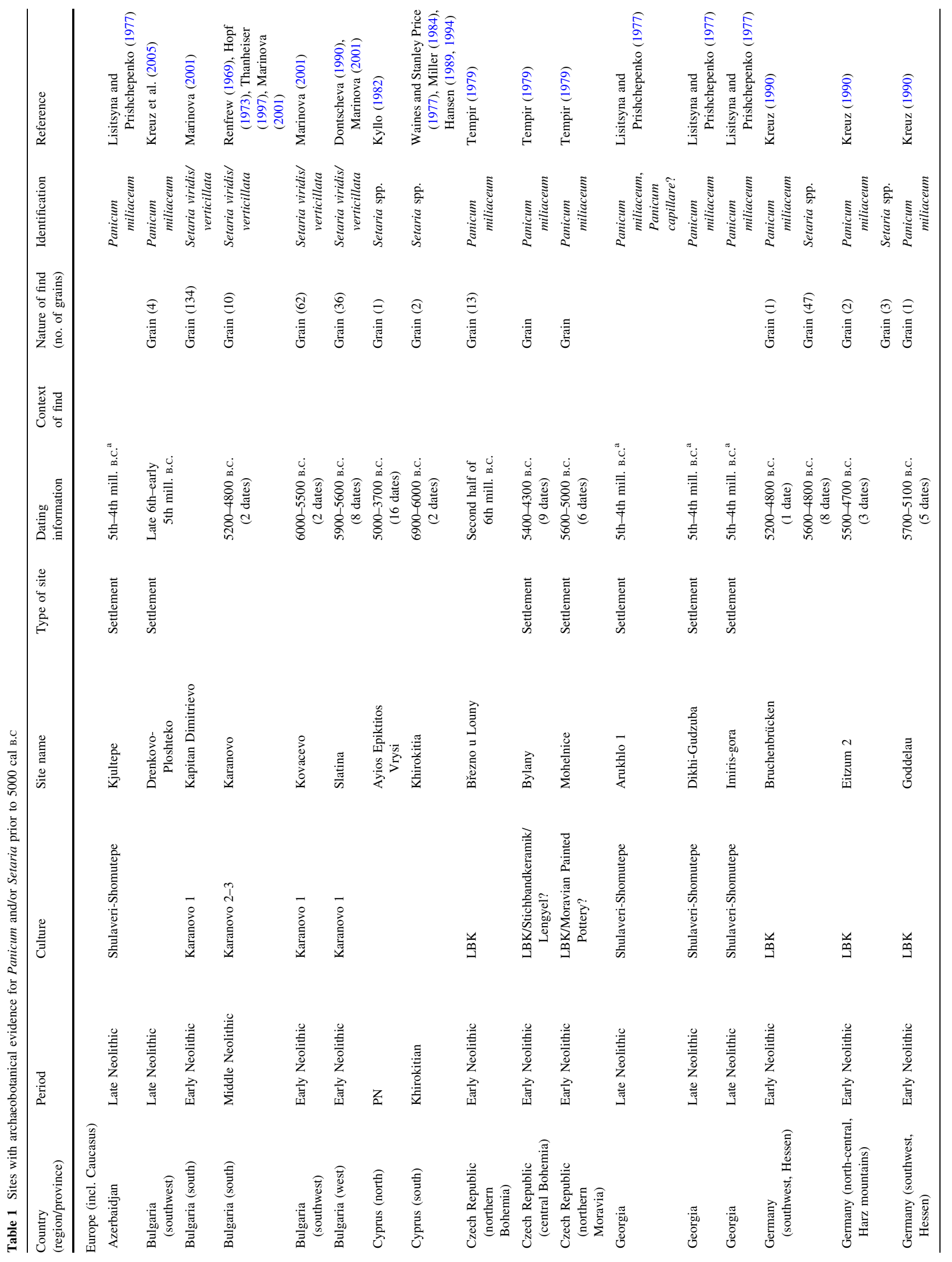




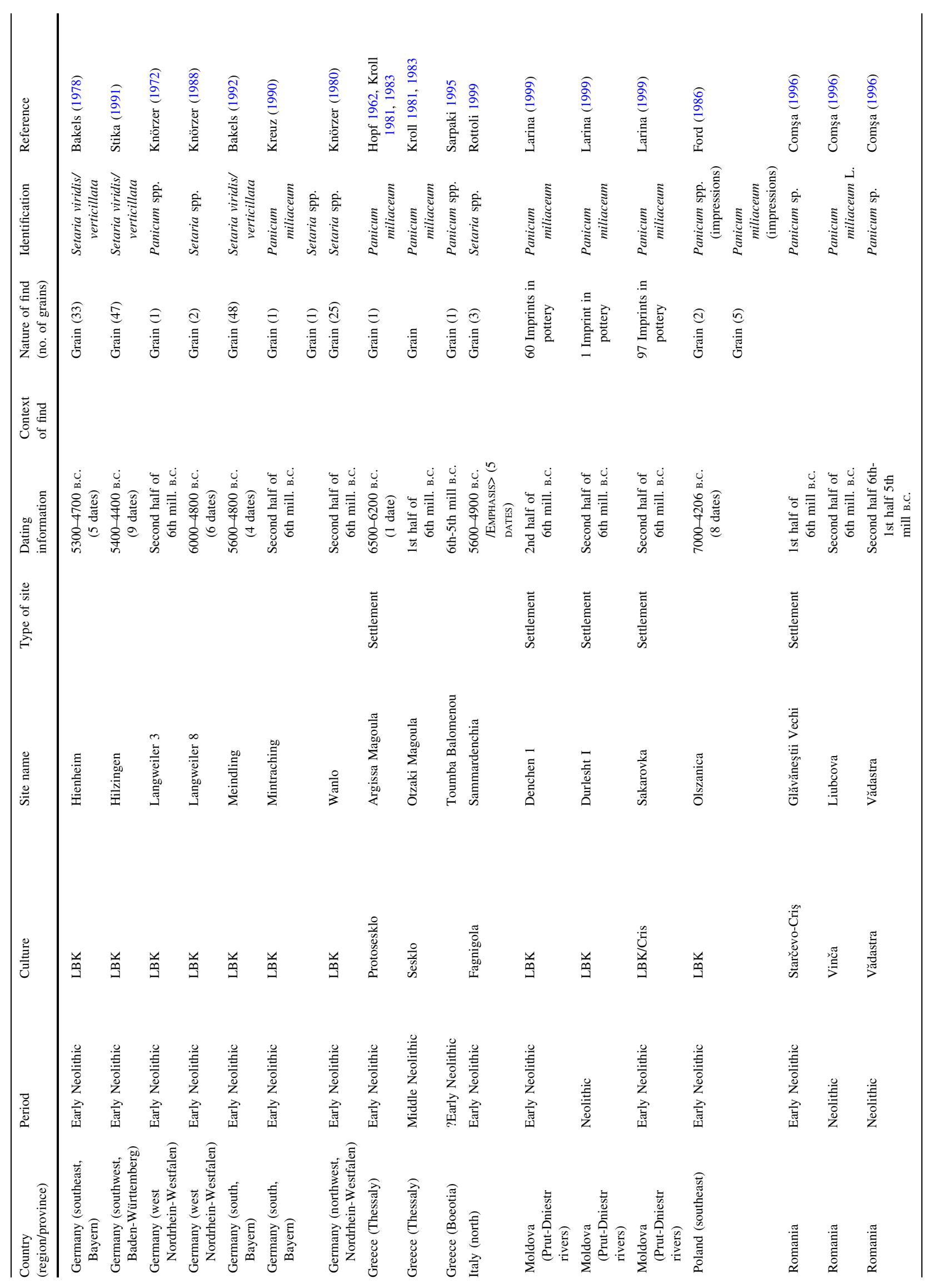




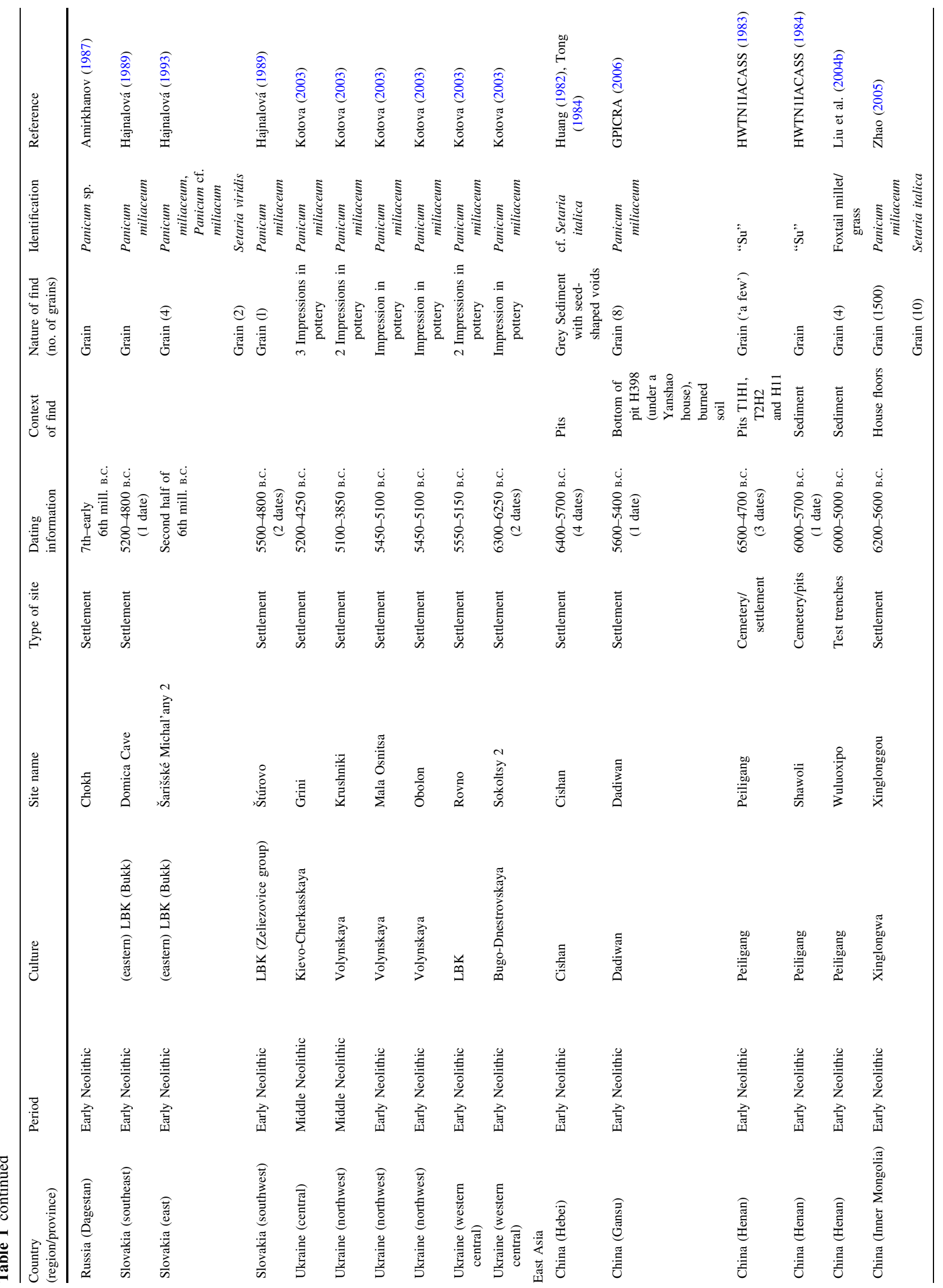




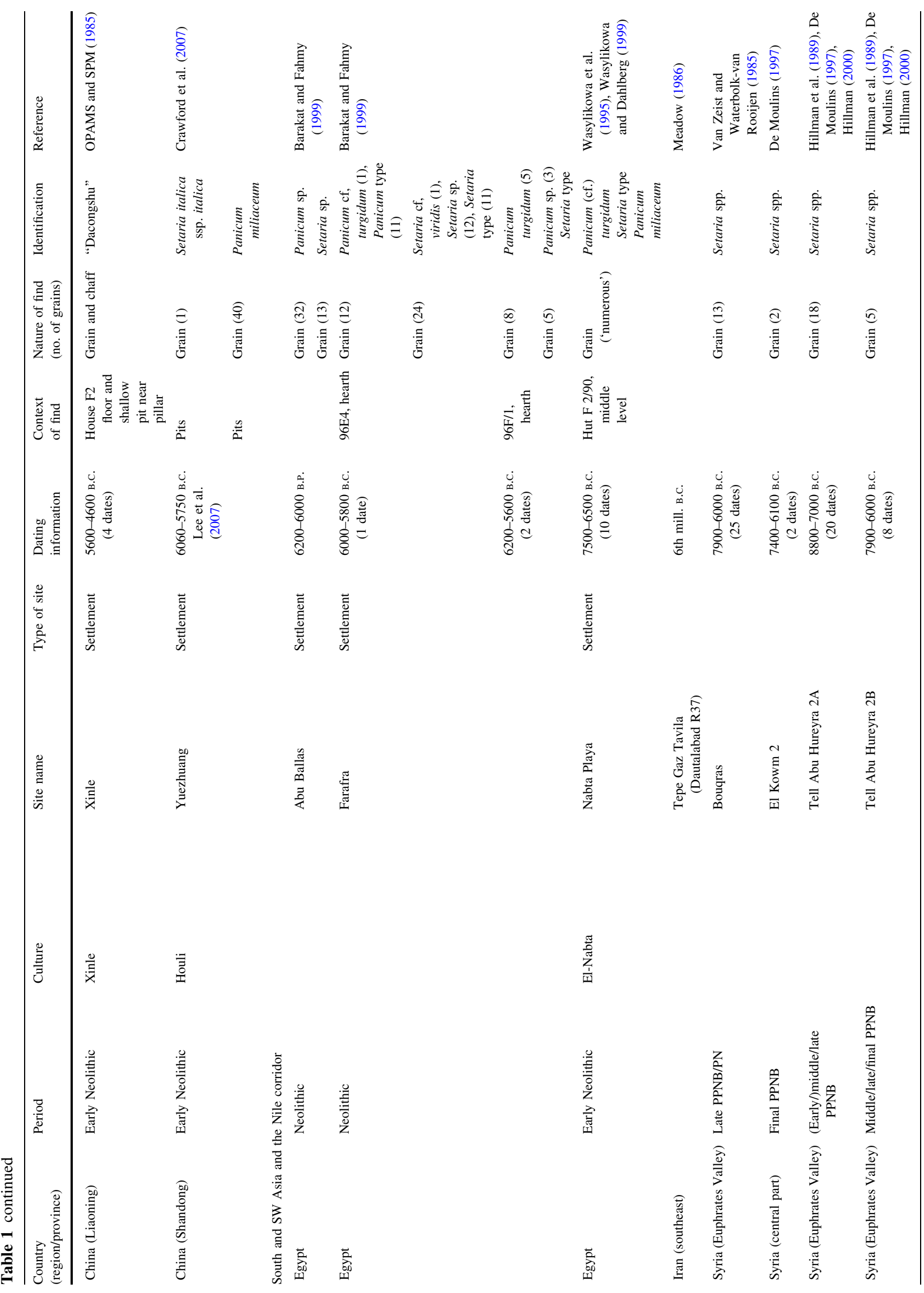




\section{Discussion}

Issues of taphonomy and identification

The data comprise evidence arising from a variety of site formation processes. Prominent among these are carbonization and impressions in either pottery or daub. From one site in China (Cishan) evidence comes in the form of 'grainshaped voids' in sediment. In some reports the evidence of the form of preservation involved is incomplete or absent. The geographical distribution of the principal evidence types is patchy, reflecting different regional traditions of archaeobotany, for example in how widespread the use of flotation has been. Consequently, the presence of carbonized grain versus impressions most likely reflects regional differences in the history of archaeological practice rather than any original patterning in the data.

Various authors have discussed identification criteria for the caryopses of carbonized $P$. miliaceum and $S$. italica found in archaeological sites of a variety of dates (Knörzer 1971; Kroll 1983; Nesbitt and Summers 1988; Liu and Kong 2004; Fuller 2006; Fuller and Zhang 2007; Nasu et al. 2007). The last report presents excellent grain measurements and photographs of modern reference specimens of ten Setaria taxa. All other publications deal with both genera and mention that the caryopses of $P$. miliaceum and $S$. italica are different in general shape. Grains of P. miliaceum typically have a pointed distal ('top') end and relatively blunt proximal ('bottom') end, while grains of $S$. italica are gently rounded at both ends (Nesbitt and Summers 1988).

A second key identification criterion all the authors mention is the size of the embryo pit. Knörzer (1971) and Nesbitt and Summers (1988) recognize that the embryo pit of $P$. miliaceum is 'short and wide', $40-60 \%$ of grain length (maximum 70\%). The groove of S. italica, however, is much longer and narrower than in broomcorn millet, almost always over $65 \%$ of grain length, usually averaging 70-80\%. Kroll (1983) states that the embryo pit of $P$. miliaceum is smaller than half the grain length. Fuller (2006) generalizes that the embryo pit of Panicum spp. is around half of grain length, ranging up to two-thirds, while Setaria spp. are markedly longer than half, usually exceeding two-thirds.

A third criterion is the morphological pattern of lemma and palea under the microscope. In the earlier publications (Knörzer 1971; Nesbitt and Summers 1988), they state that the charred husk fragments of $P$. miliaceum are smooth and glossy, and the ones of $S$. italica vary from finely rugose to punctuate. The later references present good SEM images of husks (Fuller 2006). In addition, Nesbitt and Summers (1988) argued that in P. miliaceum the husks often adhere to the charred caryopses. 


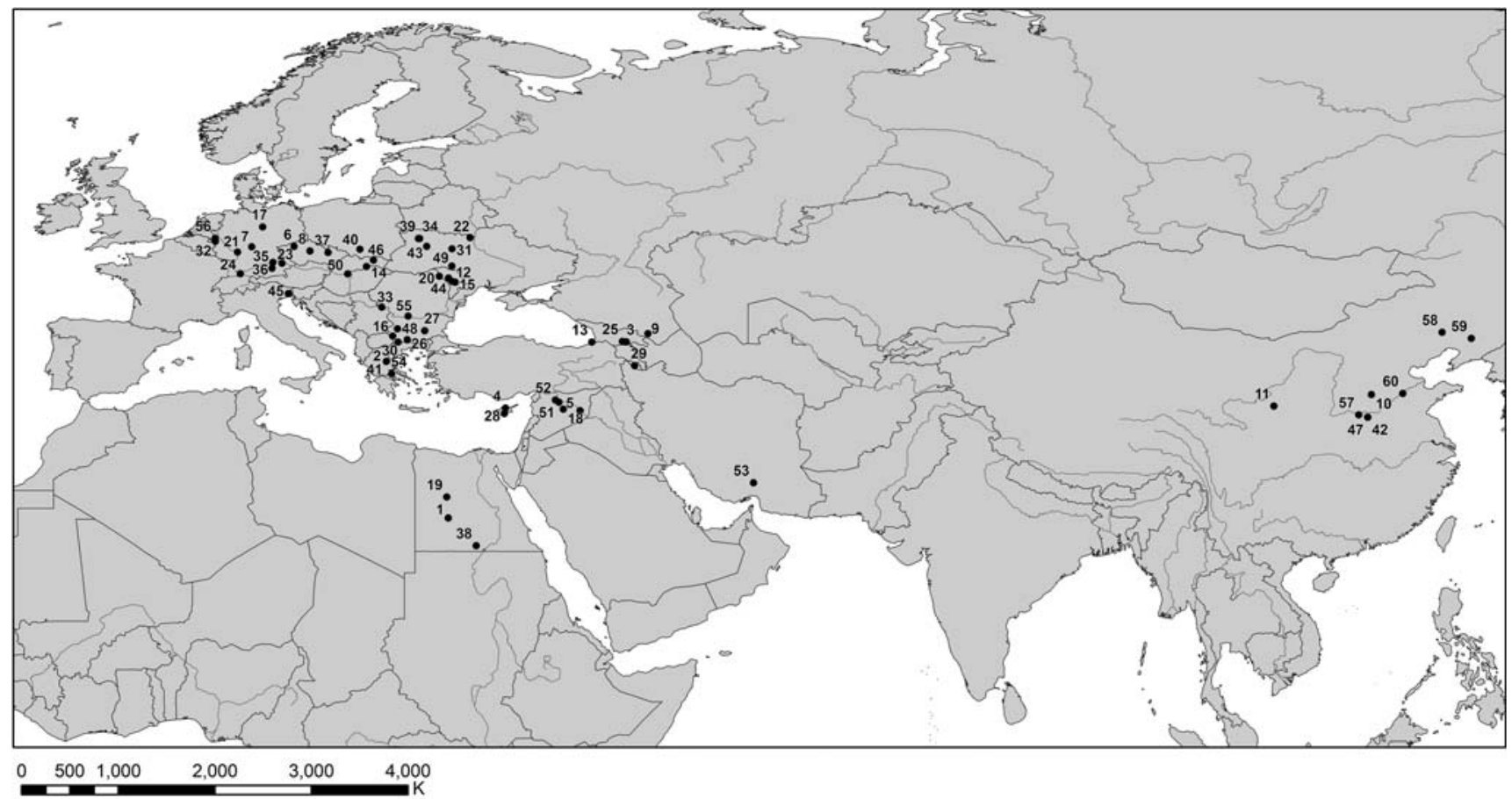

Fig. 1 Sites pre 5000 cal B.c. with archaeobotanical remains of Panicum and/or Setaria. 1 Abu Ballas; 2 Argissa Magoula; 3 Arukhlo 1; 4 Ayios Epiktitos Vrysi; 5 Bouqras; 6 Březno u Louny; 7 Bruchenbrücken; 8 Bylany; 9 Chokh; 10 Cishan; 11 Dadiwan; 12 Denchen1; 13 Dikhi-Gudzuba; 14 Domica Cave; 15 Durlesht1; 16 Drenkovo-Ploshteko; 17 Eitzum 2; 18 El Kowm 2; 19 Farafra; 20 Glăvăneştii Vechi; 21 Goddelau; 22 Grini1; 23 Hienheim; 24 Hilzingen; 25 Imirisgora; 26 Kapitan Dimitrievo; 27 Karanovo; 28

Numbers of identifications by nomenclature in this data set are summarized in Table 2. With a few exceptions, the reports relevant to the period covered by this paper do not allude to the above identification criteria, but simply present taxon names. Moreover, identification is not always reported consistently between (and sometimes even within) publications. For example, Lisitsyna and Prishchepenko (1977) list P. miliaceum L. at the Shulaveri-Shomutepe sites of Arukhlo I, Dikhi-Gudzuba and Imirisgora, but in a later review (Lisitsyna 1984), these identifications are revised to 'Panicum sp.', without explanation. In a more common scenario, original genuslevel identifications are elsewhere 'upgraded' to specific identification of a species of palaeoethnobotanical interest. For example, Barakat and Fahmy present a detailed table of the results of archaeobotanical analysis from Abu Ballas in which a total of 32 grains of 'Panicum sp.' and 13 of 'Setaria sp.' from a range of sediment samples are recorded (1999, Table 2, p. 39); however, a summary table (Barakat and Fahmy 1999, Table 3, p. 40) comparing grass taxa at multiple sites, and subsequent discussion, refer to ' $P$. turgidum'; the same table refers to ' $S$. viridis', but the text states that further morphological investigations are under way to identify the grains of
Khirokitia; 29 Kjultepe; 30 Kovacevo; 31 Krushniki 2; 32 Langweiler; 33 Liubcova; 34 Mala Osnitsa1; 35 Meindling; 36 Mintraching; 37 Mohelnice; 38 Nabta Playa; 39 Obolon1; 40 Olszanica; 41 Otzaki Magoula; 42 Peiligang; 43 Rovno; 44 Sakarovka; 45 Sammardenchia; 46 Šrišské Michal'any 2; 47 Shawoli; 48 Slatina; 49 Sokoltsy 2; 50 Štúrovo; 51 Tell Abu Hureyra; 52 Tell Mureybit; 53 Tepe Gaz Tavila (Dautalabad R37); 54 Toumba Balomenou; 55 Vădastra; 56 Wanlo; 57 Wuluoxipo; 58 Xinglonggou; 59 Xinle; 60 Yuezhuang

Table 2 Summary of identifications of Panicum and Setaria in the current data set by nomenclature

\begin{tabular}{lc}
\hline Identification & Number of ident. \\
\hline Panicum miliaceum & 31 \\
Panicum cf. miliaceum & 1 \\
Panicum capillare? & 1 \\
Panicum turgidum & 1 \\
Panicum (cf.) turgidum & 2 \\
Panicum sp(p). & 8 \\
Panicum type & 1 \\
Dacongshu' (Chinese, 'onion broomcorn millet') & 1 \\
Setaria italica ssp. italica & 1 \\
Setaria italica & 1 \\
cf. Setaria italica & 1 \\
Su' (Chinese, 'foxtail millet') & 2 \\
Foxtail millet/grass & 1 \\
Setaria viridis & 1 \\
Setaria cf. viridis & 1 \\
Setaria viridis/verticillata & 7 \\
Setaria sp(p). & 16 \\
Setaria type & 3 \\
\hline
\end{tabular}


'Setaria type' from Abu Ballas accurately to species level. Such inconsistencies may seem trivial in the context of an individual report, but they have knock-on effects in the secondary literature. This is not to single out the authors above for particular criticism-there is a universal tendency to simplify the complex details of primary data sets to provide a concise synthesis.

In some cases the specificity of identification may have arisen from a circular argument-that Setaria sp. remains from Neolithic China may be discussed as possible cultivated foxtail millet, $S$. italica, because we expect to find this taxon there, whereas Setaria sp. identifications from Egypt are assumed to be part of a different archaeological 'story', and ignored in the former context. The lack of photographs or morphological details in reports from excavations of the 1970s/1980s in the key regions of China and the Caucasus makes it difficult to assess these records critically. Some authors have arrived at their own judgements on which records are dubious and should be discounted (see, for example, Nesbitt and Summers 1988). A further problem is posed by reports where botanical identifications are only given in the vernacular. The excavation report for Peiligang (HWTN1IACASS (Henan Working Team No. 1, Institute of Archaeology, Chinese Academy of Social Science) 1983) notes the presence of su-(S. italica, foxtail millet), while a Chinese book of the same year, The history of Chinese Cultivated Plants, reports that grains shaped like $j i$, which the author defines as sticky-type broomcorn millet, were found at Peiligang (Li 1984). Subsequent papers quoting both S. italica and P. miliaceum at Peiligang (Ren 1995; Underhill 1997) may represent an amalgamation of these two contemporary Chinese sources. We have listed Setaria only at Peiligang, in keeping with the primary report. At Cishan, $S$. italica was identified on the basis of seed-shaped voids in sediment (Huang 1982), of which no record has been kept. In the last decade, the introduction of flotation to Chinese archaeology, for example by Zhao (2004) at Xinglonggou and Crawford et al. (2007) at Yuezhuang, has resulted in substantially more robust evidence with the recovery and direct dating of broomcorn and foxtail millet macrofossils.

Identifying domestication, cultivation and crop/weed status

Setaria viridis has been conclusively identified as the wild ancestor of $S$. italica on the basis of morphology, interspecific crosses and AFLP analysis (Le Thierry d'Ennequin et al. 2000), but the wild ancestry of $P$. miliaceum remains uncertain. The most plausible candidate is a weedy taxon, $P$. miliaceum ssp. ruderale, which grows as a weed of maize and millet crops in China today. According to
Zohary and Hopf (2000) this taxon grows west to the Aralo-Caspian basin, but a morphologically similar weed is found in central Europe (Scholz and Mikoláš 1991). Whether $P$. miliaceum ssp. ruderale constitutes a genuinely wild species or is a feral derivative of domesticated broomcorn millet, or whether, as these authors suggest, further taxonomic division of this subspecies is needed, remains an open question.

In the absence of secure knowledge about the wild ancestor, authors have speculated about familiar domestication markers such as grain size and shape. Zhao (2005) has tentatively related the wild/domesticated status of some of the $P$. miliaceum finds in northern China to variation in seed size. However, as Fuller et al. (2007) have shown for rice, grain size and shape need to be interpreted in the context of an understanding of panicle maturation patterns and the morphometry of seeds at different stages of maturity.

The clear taxonomic and morphological differentiation of domesticated $S$. italica and the wild annual weeds S. verticillata and (ancestral to $S$. italica) $S$. viridis leaves less room for ambiguity than in Panicum regarding the inferred wild/domesticated status of the finds. Crawford and Lee (mentioned in Liu et al. 2004b) assessed grains from Wuluoxipo as potential intermediates in the transition from wild to domesticated foxtail millet on the basis of dorsal flattening of the grain. The dataset contains a number of identifications of 'Setaria spp.' in Epipalaeolithic and Neolithic Syria, Cyprus, and central Europe. These are usually assumed (explicitly or otherwise) to represent one of the two wild species above, since there is no concrete evidence for S. italica until the Iron Age in the Near East (Nesbitt and Summers 1988) and until the Bronze Age in central Europe (Zohary and Hopf 2000).

In contrast, the only non-miliaceum species-level identifications of Panicum are $P$. turgidum in Egypt, of palaeoethnobotanical interest in its own right but distinct from broomcorn millet domestication history, and a tentative identification of $P$. capillare in the Caucasus (Lisitsyna and Prishchepenko 1977). P. capillare is a native of North America naturalized in Europe (Tutin 1980), so unless this find represents an intrusion or the chronology is wrong, this identification is unlikely to be correct. The Panicum flora of Europe is species-poor (Panicum is primarily a tropical genus) and only one native wild species, other than $P$. miliaceum ssp. ruderale, is widespread in Europe, $P$. repens (Tutin 1980). Probably for this reason, there has been no discussion to date of the morphology of wild Panicum species or their possible presence as weeds in assemblages, although such a study would be pertinent to China, which has a number of native wild Panicum species (Wu and Raven 2007). While the presence of $S$. viridis and $S$. verticillata as natives 
throughout much of Europe makes this the 'default' interpretation for records of Setaria sp., the absence of clear-cut wild Panicum species (given the uncertainty of the status of $P$. miliaceum ssp. ruderale) accounts for the recurrent inference that generic level archaeobotanical identifications of Panicum sp. represent domesticated broomcorn millet. Explicit discussion is needed on morphology of Panicum and allied genera to clarify which species might potentially be indicated by an identification of 'Panicum sp.'

A closely related issue to that of wild/domesticated plant forms is whether the millets were being cultivated as crops or alternatively existed as weeds. Some authors have explicitly interpreted rare or solitary finds as arable weeds, and/or only inferred intentional cultivation where large quantities of grain are present. (Nesbitt and Summers 1988; Kreuz et al. 2005). The latter authors consider that the presence of $P$. miliaceum from four LBK sites in Germany as only single seeds reflects its status as a weed of the major crops (einkorn and emmer wheat), introduced in seedcorn. P. miliaceum ssp. ruderale and similar types with wild-type seed dispersal behaviour are significant arable weeds in several parts of the world today: China, central Europe (Scholz and Mikoláš 1991), and North America (Bough et al. 1986). It is plausible that such types were also weeds in prehistory, either as truly wild taxa, or derived from domesticated non-shattering P. miliaceum by backmutation. However, grain quantities have at best an indirect relationship with grain use, let alone grain domestication. Our growing awareness of taphonomy and site formation processes has brought to light a range of quite separate factors that may determine numerical composition of assemblages (Hubbard and Clapham 1992). We should also bear in mind that the sharp distinction in modern agriculture between 'crop' and 'weed' need not necessarily have been as sharp, or indeed applied at all, among Neolithic people.

Implications for the origins of domesticated broomcorn and foxtail millet

More can currently be said with confidence about the origins of domesticated $S$. italica than $P$. miliaceum. The distinction between domesticated foxtail millet and its wild relatives is established, and, as argued above, this has knock-on effects for nomenclatural clarity and the botanical framework in which identification of archaeological samples is carried out. Although the progenitor $S$. viridis is widespread in Eurasia, and this appears to have been the case in prehistory too, S. italica is found before 5000 cal в.c. only in China. Unfortunately, the records from the two most widely mentioned sites, Peiligang and Cishan, are enigmatic (see above). However, new site excavations at Xinglonggou and Yuezhuang attest to the presence of $S$. italica as early as the late seventh millennium B.c. in northern China. Analysis of intraspecific genetic polymorphisms at ribosomal and mitochondrial loci supports eastern Asia as a centre of origin of foxtail millet (Fukunaga et al. 2002, 2006; Fukunaga and Kato 2003). The genetic data also indicate an independent domestication of landraces in Afghanistan and northwestern Pakistan ( $\mathrm{Li}$ et al. 1995; Fukunaga et al. 2006). An independent origin of foxtail millet landraces in tropical eastern Asia, including Taiwan and the Philippines, is also possible, but the complicated evolution of the ribosomal markers used in this study means that this is still uncertain (Fukunaga et al. 2006). The discovery of foxtail millet at Chengtoushan at 3850 cal в.c. has also led to the hypothesis that it was domesticated separately in south-central China, alongside rice (Nasu et al. 2007).

Polymorphic genetic markers that have the potential to reveal geographic patterns in $P$. miliaceum have not yet been described in the literature. We are currently undertaking marker development to address this problem. The most plentiful early records of broomcorn millet appear in two regions. Xinglonggou, Yuezhuang and Dadiwan in northern China have yielded 1500, 40 and 8 carbonized grains, respectively. Pottery from two sites in Moldova, Denchen and Sakarovka, has, respectively, produced 97 and 60 impressions. We note that a great number of the remaining early records are of single grains, which, as mentioned above, have prompted some authors to speculate on its status. Whatever that status might be in different regions, crop, weed or intermediate form, the question of its dispersal across Eurasia remains. Crucial to answering this are the status and chronology of finds from the northern Black Sea region and the Caucasus, which require re-evaluation.

\section{Ecological considerations}

We would infer from the geographical distribution indicated in Map 1 that the great majority of domesticated millet records prior to 5000 B.c. could have arisen from rainfed summer crops, without the need for any form of irrigation. Such an inference demands closer scrutiny of records from southeastern Europe and southern Iran. Four records from Bulgaria and Greece specify either Panicum or $P$. miliaceum. The varied topography around each of the sites concerned does permit a combination of seasonal sowing patterns, and the most southerly of these records, from Toumba Balomenou, Chaeronia, Greece, occurs in conjunction with weed evidence of summer sowing of at least some crops (Sarpaki 1995). The Iranian record from Tepe Gaz Tavila is more anomalous in ecological terms. 
This record has not however yet reached primary archaeobotanical publication.

\section{Conclusions}

Archaeobotanical data underpins a range of recent and ongoing complementary archaeological science projects researching the origins of millet agriculture: stable isotope analysis (Hu et al. 2006), genetics (Fukunaga et al. 2002, 2006; Fukunaga and Kato 2003) and lipid analysis from sediment cores (Jacob et al. 2008).

The data assembled here have emphasized the contrasting patterns for the two principal Eurasian millets, $P$. miliaceum and S. italica. Both occur prior to $5000 \mathrm{cal}$ B.c. in North China, but only P. miliaceum occurs prior to 5000 cal B.C. in western Asia and Europe. Within the P. miliaceum distribution, there is a marked contrast in numerical abundance between records, which some authors have related to crop/weed status. This review emphasizes the need for researchers across diverse disciplines to engage with the complexities and points of debate in the archaeobotanical data that pertain to the agrarian prehistory of these crops.

Not all domestication events need be associated with a pre-5000 cal в.с. archaeobotanical signature-independent domestications may have happened at a later date. However, discussion of millet domestication has stemmed largely from the geographical distribution of the earliest finds, which, given their rarity at this early date and the obscurity of some records, renders them critical.

The current archaeobotanical record does not allow discrimination between hypotheses of single versus multiple domestications, or of subsequent diffusion pathways, of $P$. miliaceum and $S$. italica. The key issues for future archaeobotanical research on these crops are the need for unified and transparent criteria for taxonomic identification, the more consistent application of flotation techniques, and the need to fill gaps in the record, particularly over large areas of central Asia.

Acknowledgments H. V. H. was supported by a Wellcome Trust Research Training Fellowship (ref. 076815), M. V. by the project The Formation of Europe: population dynamics and the roots of sociocultural diversity (European commission Specific Targeted Research Project no. 028192), G. M. by the Gates Foundation, X. L. by a University of Cambridge Dorothy Hodgkin studentship. We are grateful to Loukas Barton, James Conolly, Stephen Shennan, Helmut Kroll, and Zhao Zhijun for assistance finding data and for constructive comments. Thanks to Cameron Petrie for data mapping. We thank two anonymous referees for their constructive criticisms of the manuscript. Any remaining errors are our own.

Open Access This article is distributed under the terms of the Creative Commons Attribution Noncommercial License which permits any noncommercial use, distribution, and reproduction in any medium, provided the original author(s) and source are credited.

\section{References}

Amirkhanov KA (1987) Chokhskoe poselenie: chelovek i ego kultura v mezolite i neolite gornogo Dagestana. (Chokh settlement: man and his culture in the Mesolithic and Neolithic of mountainous Dagestan, in Russian). Nauka, Moscow

Bakels CC (1978) Four Linearbandkeramik settlements and their environment: a palaeoecological study of Sittard, Stein, Elsloo and Hienheim. Analecta Praehist Leiden 11:1-248

Bakels CC (1992) Fruits and seeds from the Linearbandkeramik settlement at Meindling, Germany, with special reference to Papaver somniferum. Analecta Praehist Leiden 25:55-68

Barakat H, Fahmy AGe-D (1999) Wild grasses as 'Neolithic' food resources in the eastern Sahara. In: Van der Veen M (ed) The exploitation of plant resources in ancient Africa. Kluwer, New York, pp 33-46

Bough M, Colosi JC, Cavers PB (1986) The major weedy biotypes of proso millet (Panicum miliaceum) in Canada. Can J Bot 64:1188-1198

Bronk Ramsey C (2001) Development of the radiocarbon calibration program OxCal. Radiocarbon 43:355-363

Cohen DJ (1998) The origins of domesticated cereals and the Pleistocene-Holocene transition in East Asia. Rev Archaeol 19:22-29

Colledge S, Conolly J, Shennan S (2004) Archaeobotanical evidence for the spread of farming in the Eastern Mediterranean. Curr Anthropol 45:S35-S58

Colledge S, Conolly J, Shennan S (2005) The evolution of Neolithic farming from SW Asian origins to NW European limits. Eur J Archaeol 8:137-156

Comşa E (1996) Viaţa oamenilor din spaţiul Carpato-DanubianaPontic în mileniile 7-4î hr (The life of people in the CarpathoDanubian-Pontic region in the 7th-4th millennia B.C., in Romanian). Ed didactică şi pedagogică, Bucharest

Crawford GW (1992) Prehistoric plant domestication in East Asia. In: Cowan CW, Watson PJ (eds) The origins of agriculture: an international perspective. Smithsonian Institution Press, Washington, pp 7-38

Crawford GW, Chen X, Wang J (2007) Shandong Jinan changqing qu Yuezhuang yizhi faxian Houli wenhua shiqi de tanhua dao (Houli culture rice from the Yuezhuang site, Jinan, in Chinese). Dongfang Kaogu (Orient Archaeol) 3:247-251

De Moulins D (1997) Agricultural changes at Euphrates and steppe sites in the mid-8th to the 6th millennium B.c. BAR international series, vol 683. John and Erica Hedges, Oxford

Dontscheva E (1990) Plant macrorest research of early Neolithic dwellings in Slatina. Stud Praehist 10:86-90

Ford RI (1986) Appendix G. The archaeobotany of Olszanica, Poland. In: Milisauskas S (ed) Early Neolithic settlement and society at Olszanica. Memoirs of the museum of anthropology, vol 19. University of Michigan, Ann Arbor, pp 261-265

Fukunaga K, Wang Z, Kato K, Kawase M (2002) Geographical variation of nuclear genome RFLPs and genetic differentiation in foxtail millet, Setaria italica (L.) P. Beauv. Genet Resour Crop Evol 49:95-101

Fukunaga K, Kato K (2003) Mitochondrial DNA variation in foxtail millet, Setaria italica (L.) P. Beauv. Euphytica 129:7-13

Fukunaga K, Ichitani K, Kawase M (2006) Phylogenetic analysis of the rDNA intergenic spacer subrepeats and its implication for the 
domestication history of foxtail millet, Setaria italica. Theor App Genet 113:261-269

Fuller DQ (2006) A millet atlas-some identification guidance. Institute of Archaeology, University College London. http://www.homepages.ucl.ac.uk/ tcrndfu/Abot/ Millet\%20Handout06.pdf. Accessed 21 Apr 2008

Fuller DQ, Harvey E, Ling Q (2007) Presumed domestication? Evidence for wild rice cultivation and domestication in the fifth millennium B.c. of the lower Yangtze region. Antiquity 81:316331

Fuller DQ, Zhang H (2007) A preliminary report of the survey archaeobotany of the upper Ying Valley (Henan Province). In: SAMPU and HPIACR (eds) Dengfeng Wangchenggang yizhi de faxian yu yanjiu (2002-2005) (Archaeological discovery and research at the Wangchenggang site in Dengfeng (2002-2005), in Chinese). Great Elephant, Zhengzhou, pp 916-958

GPICRA (Gansu Province Institute of Cultural Relics, Archaeology) (2006) Qinan Dadiwan-Xinshiqi Shidai Yizhi Fajue Baogao (Dadiwan, Qinan-Report on the excavation at a Neolithic site, in Chinese). Cultural Relics Publishing House, Beijing

Hajnalová E (1989) Katalóg zvyskov semien a plodov v archeologickych nálezoch na Slovensku (Catalogue of seeds and fruits from archaeological sites in Slovakia, in Slovak). Acta Interdiscip Archaeol 6:3-192

Hajnalová E (1993) Praveké osídlenie lokality Šarišské Michal'any dokumentované rastlinnými zvyškami (The prehistoric occupation of the Šarišské Michal'any site, as attested by plant remains, in Slovak). Východoslovenský Pravek (East Slovakian Prehistory) 4:49-65

Hansen J (1989) Khirokitia plant remains: preliminary report (19801981, 1983). In: Le Brun A (ed) Fouilles récentes à Khirokitia (Chypre) 1983-1986. Études néolithiques. Éditions Recherche sur les Civilisations, Paris, pp 235-250

Hansen J (1994) Khirokitia plant remains: preliminary report (1986, 1988-1990). In: Le Brun A (ed) Fouilles récentes à Khirokitia (Chypre) 1988-1991. Études néolithiques. Éditions Recherche sur les Civilisations, Paris, pp 391-409

Hillman GC, Colledge S, Harris D (1989) Plant-food economy during the Epipalaeolithic period at Tell Abu Hureyra, Syria: dietary diversity, seasonality, and modes of exploitation. In: Harris DR, Hillman GC (eds) Foraging and farming. Unwin Hyman, London, pp 240-266

Hillman GC (2000) The Plant food economy of Abu Hureyra 1 and 2. In: Moore AMT, Hillman GC, Legge AJ (eds) Village on the Euphrates: from foraging to farming at Abu Hureyra. Oxford University Press, Oxford, pp 327-422

Hopf M (1962) Bericht über die Untersuchungen von Samen und Holzkohlenresten von der Argissa-Magula aus den präkeramischen bis mittelbronzezeitlichen Schichten. In: Milojčić V, Boessneck JM, Hopf M (eds) Die deutschen Ausgrabungen auf der Argissa-Magula in Thessalien, vol 1, pp 101-110

Hopf M (1973) Frühe Kulturpflanzen aus Bulgarien. Jahrb RGZM Mainz 20:1-55

$\mathrm{Hu}$ Y, Ambrose SH, Wang C (2006) Stable isotopic analysis of human bones from Jiahu site, Henan, China: implications for the transition to agriculture. J Archaeol Sci 33:1319-1330

Huang Q (1982) Huixiang fa zai kaogu xue zhong de yingyong (The application of ash analysis in archaeology, in Chinese). Kaogu (Archaeology) 181:418-420

Hubbard RNLB, Clapham A (1992) Quantifying macroscopic plant remains. Rev Palaeobot Palynol 73:117-132

HWTN1IACASS (Henan Working Team No. 1, Institute of Archaeology, Chinese Academy of Social Science) (1983) Henan Xinzheng Shawoli xinshiqi shidai yizhi (Shawoli, a Neolithic site in Xinzheng, Henan province, in Chinese). Kaogu (Archaeology) 195:1057-1065
HWTN1IACASS (Henan Working Team No. 1 of Institute of Archaeology, Chinese Academy of Social Science) (1984) Peiligang yizhi 1979 fajue nian baogao (Report on the excavation at Peiligang site in 1979, in Chinese). Kaogu Xuebao (Acta Archaeol Sin) 72:23-52

IACASS (Institute of Archaeology, Chinese Academy of Social Science) (1991) Zhongguo kaogu xue zhong tan shisi niandai shuju ji: 1965-1991 (Radiocarbon Dates in Chinese Archaeology: 1965-1991, in Chinese). Cultural Relics Publishing House, Beijing

Jacob J, Disnar J-R, Arnaud F, Chapron E, Debret M, Lallier-Vergès E, Desmet M, Revel-Rolland M (2008) Millet cultivation history in the French Alps as evidenced by a sedimentary molecule. J Archaeol Sci 35:814-820

Jones MK (2004) Between fertile crescents: minor grain crops and agricultural origins. In: Jones MK (ed) Traces of ancestry: studies in honour of Colin Renfrew. Oxbow Books, Oxford, pp $127-135$

Knörzer K-H (1971) Eisenzeitliche pflanzenfunde im rheinland. Bonn Jahrb 171:40-58

Knörzer K-H (1972) Subfossile Pflanzenreste aus der bandkeramischen Siedlung Langweiler 3 and 6, Kreis Jülich, und ein urnenfelderzeitlicher Getreidefund innerhalb dieser Siedlung. Bonn Jahrb 172:395-403

Knörzer K-H (1980) Pflanzliche Großreste des bandkeramischen Siedlungsplatze Wanlo (Stadt Mögchengladbach). ArchaeoPhysika 7:7-20

Knörzer K-H (1988) Untersuchungen der Früchte und Samen. In: Boelicke U, von Brandt D, Lüning J, Stehli P, Zimmerman A (eds) Der bandkeramische Siedlungsplatz Langweiler 8, Gemeinde Aldenhoven, Kreis Düren. Rheinland-Verlag, Köln, pp 813-852

Kotova NS (2003) Neolithization in Ukraine. BAR international series, vol 1109. Archaeopress, Oxford

Kreuz A (1990) Die ersten Bauern Mitteleuropas-eine archäobotanische Untersuchung zur Umwelt und Landwirtschaft der Ältesten Bandkeramik. Analecta Praehist Leiden 23:1-256

Kreuz A, Marinova E, Schäfer E, Wiethold J (2005) A comparison of early Neolithic crop and weed assemblages from the Linearbandkeramik and the Bulgarian Neolithic cultures: differences and similarities. Veget Hist Archaeobot 14:237-258

Kroll H (1981) Thessalische Kulturpflanzen. Z Archäol 15:97-103

Kroll H (1983) Kastanas. Ausgraben in einem Siedlungshügel der Bronze- und Eisenzeit Makedoniens 1975-1979. Spiess, Berlin

Kroll H (1996) Literature on archaeological remains of cultivated plants (1994/95). Veget Hist Archaeobot 5:169-200

Kroll H (1997) Literature on archaeological remains of cultivated plants (1995/1996). Veget Hist Archaeobot 6:25-67

Kroll H (1998) Literature on archaeological remains of cultivated plants (1996/1997). Veget Hist Archaeobot 7:23-56

Kroll H (1999) Literature of archaeological remains of cultivated plants (1997/1998). Veget Hist Archaeobot 8:129-163

Kroll H (2000) Literature on archaeological remains of cultivated plants (1998/1999). Veget Hist Archaeobot 9:31-68

Kroll H (2001) Literature on archaeological remains of cultivated plants (1999/2000). Veget Hist Archaeobot 10:33-60

Kroll H (2005) Literature on archaeological remains of cultivated plants 1981-2004. http://www.archaeobotany.de/database.html. Accessed 30 Oct 2007

Kyllo M (1982) The Botanical remains. In: Peltenberg EJ (ed) Vrysi. A subterranean settlement in Cyprus. Excavations at Prehistoric Ayios Epiktitos Brysi 1969-1973. Aris and Phillips, Warminster, pp 90-93

Larina OV (1999) Kultura Lineino-lentochnoi Keramiki PrutoDnestrovskogo regiona (LBK cultures in the Prut-Dnester region, in Russian). Stratum Plus 2:10-140 
Le Thierry d'Ennequin M, Penaud O, Toupance B, Sarr A (2000) Assessment of genetic relationships between Setaria italica and its wild relative $S$. viridis using AFLP markers. Theor App Genet 100:1061-1066

Lee G, Crawford GE, Liu L, Chen X (2007) Plants and people from the early Neolithic to Shang periods in North China. Proc Nat Acad Sci 104:1087-1092

Li F (1984) Zhongguo Zaipei Zuowu Fazhanshi (The history of cultivated plants in China, in Chinese). Science Publishing House, Beijing

Li Y, Wu SZ, Cao YS (1995) Cluster analysis of an international collection of foxtail millet (Setaria italica (L.) P. Beauv.). Euphytica 83:79-85

Lisitsyna GN, Prishchepenko LV (1977) Paleo-etnobotanicheskie nakhodki Kavkaza i Blizhnego Vostoka. (Palaeoethnobotanical finds of the Caucasus and the Near East, in Russian). Nauka, Moscow

Lisitsyna GN (1984) The Caucasus - a centre of ancient farming in Eurasia. In: Van Zeist W, Casparie WA (eds) Plants and ancient man. Balkema, Rotterdam, pp 285-292

Liu C, Kong Z (2004) Su shu zili de xingtai bijiao jiqi zai kaogu jianding zhong de yiyi (Morphological comparison of foxtail millet and broomcorn millet and its significance in archaeological identification, in Chinese). Kaogu (Archaeology) 443:76-83

Liu C, Kong Z, Lang SD (2004a) Dadiwan yizhi nongye zhiwu yicun yu renlei shengcun huanjing de tantao (A discussion on agricultural and botanical remains and the human ecology of Dadiwan site, in Chinese). Zhongyuan Wenwu (Cultural Relics Central China) 4:25-29

Liu L, Chen X, Lee YK, Wright H, Rosen A (2004b) Settlement patterns and development of social complexity in the Yiluo region, North China. J Field Archaeol 29:75-100

Lu TL-D (2005) The origin and dispersal of agriculture and human diaspora in East Asia. In: Blench RM, Sagart L, Sanchez-Mazas A (eds) The peopling of east Asia: putting together archaeology, linguistics and genetics. Curzon, London, pp 51-62

Marinova EM (2001) Vergleichende paläoethnobotanische Untersuchung zur Vegetationsgeschichte und zur Entwicklung der prähistorischen Landnutzung in Bulgarien. Doctoral thesis, Rheinischen Friedrich-Wilhelms Universität, Bonn

Marinval P (1995) Données carpologiques françaises sur les Millets (Panicum miliaceum L. et Setaria italica (L.) Beauv.) de la Protohistoire au Moyen Age. In: Hörandner E (ed) Millet-HirseMillet. Lang, Frankfurt am Main, pp 31-61

Meadow RH (1986) The geographical and palaeoenvironmental setting of Tepe Yahya. In: Lamberg-Karlovsky CC, Wight-Beale T (eds) Excavations at Tepe Yahya, Iran 1967-1975: the early periods. Harvard University Press, Cambridge, pp 21-38

Miller NF (1984) Some plant remains from Khirokitia, Cyprus: 1977 and 1978 excavations. In: Le Brun A (ed) Fouilles récentes à Khirokitia (Chypre) 1977-1981. Études néolithiques, vol 1. Éditions Recherche sur les Civilisations, Paris, pp 183-188

Nasu H, Momohara A, Yasuda Y, He J (2007) The occurrence and identification of Setaria italica (L.) P. Beauv. (foxtail millet) grains from the Chengtoushan site (ca. $5800 \mathrm{cal}$ B.P.) in central China, with reference to the domestication centre in Asia. Veget Hist Archaeobot 16:481-494

Nesbitt M (1994) Report. In: Herrmann G, Kurbansakhatov K (eds) The international Merv project: preliminary report on the second season (1993), pp 71-73. Iran 32:53-75

Nesbitt M, Summers GD (1988) Some recent discoveries of millet (Panicum miliaceum L. and Setaria italica (L.) P. Beauv.) at excavations in Turkey and Iran. Anatol Stud 38:85-97

OPAMS (Office for the Preservation of Antiquities, Municipality of Shenyang), SPM (Shenyang Palace Museum) (1985) Shenyang Xinle yizhi di erci fajue baogao (The second excavation of the
Neolithic site at Xinle in Shenyang, in Chinese). Kaogu Xuebao (Acta Archaeol Sin) 77:209-222

Ren S (1995) Gongyuan qian wuqian nian qian Zhongguo xinshiqi wenhua de jixiang zhuyao chengjiu (The main achievements of Chinese Neolithic cultures before 5000 B.C., in Chinese). Kaogu (Archaeology) 328:37-49

Renfrew JM (1969) Palaeoethnobotany and the Neolithic cultures of Greece and Bulgaria. Doctoral thesis, University of Cambridge

Rottoli M (1999) I resti vegetali di Sammardenchia-Cueis (Udine), insediamento del neolitico antico. In: Ferrari A, Pessina A (eds) Sammardenchia-Cueis: Contributi per la Conoscenza di una Communita del Primo Neolitico. (Pubblicazione n. 41) Edizione del Museo Friulano di Storia Naturale, Commune di Udine, pp 307-326

Sarpaki A (1995) Toumba Balomenou, Chaeronia: plant remains from the early and middle Neolithic levels. In: Kroll H, Pasternak R (eds) Res archaeobotanicae. International Workgroup for Palaeoethnobotany. Proceedings of the 9th symposium, Kiel 1992. Oetker-Voges, Kiel, pp 5-15

Scholz H, Mikoláš V (1991) The weedy representatives of proso millet (Panicum miliaceum, Poaceae) in Central Europe. Thaiszia 1:31-41

Shelach G (2000) The earliest Neolithic cultures of Northeast China. J World Prehist 14:363-413

Shennan S, Steele J (2000) Spatial and chronological patterns in the Neolithization of Europe. http://ads.ahds.ac.uk/catalogue/ resources.html?c14_meso. Accessed 25 Oct 2007

Shennan S, Conolly J (2007) The origin and spread of Neolithic plant economies in the Near East and Europe. http://ads.ahds.ac.uk/ catalogue/resources.html?neoplants_ahrb_2005. Accessed 21 Apr 2008

Stika HP (1991) Die paläoethnobotanische Untersuchung der linearbandkeramischen Siedlung Hilzingen, Kreis Konstanz. Fundber Bad-Württ 16:63-104

Tempir Z (1979) Kulturpflanzen im Neolithikum und Äneolithikum auf dem Gebiet von Böhmen und Mähren. Archaeo-Physika 8:303-309

Thanheiser U (1997) Botanische Funde. In: Hiller S, Nikolov V (eds) Karanovo. Die Ausgrabungen im Südsektor 1984-1992. Österreich Bulgarische Ausgrabungen in Karanovo, Berger, Horn, pp 429-454

Tong W (1984) Cishan Yizhi de Yuanshi Nongye Yicun Jiqi Xiangguan de Wenti (Remains of primitive farming at Cishan site and its related problems, in Chinese). Nongye Kaogu (Agric Archaeol) 7:36-42

Tutin TG (ed) (1980) Gramineae (Poaceae). In: Tutin TG, Heywood VH, Burges NA, Moore DM, Valentine DH, Walters SM, Webb DA (eds) Flora Europaea, vol 5. Alismataceae to orchidaceae. Cambridge University Press, Cambridge, pp 118-154

Underhill AP (1997) Current issues in Chinese Neolithic archaeology. J World Prehist 11:103-160

Van Zeist W, Bakker-Heeres JA (1984) Archaeobotanical studies in the Levant, 3. Late-Paleolithic Mureybit. Palaeohistoria 26:171199

Van Zeist W, Waterbolk-van Rooijen W (1985) The palaeobotany of Tell Bouqas, Eastern Syria. Paléorient 11:131-147

Waines JG, Stanley Price NP (1977) Plant remains from Khirokitia in Cyprus. Paléorient 3:281-284

Wasylikowa K, Cârciumaru M, Hajnalová E, Hartyányi BP, Pashkevich GA, Yanushevich ZV (1991) East-Central Europe. In: Van Zeist W, Wasylikowa K, Behre K (eds) Progress in Old World palaeoethnobotany. Balkema, Rotterdam, pp 207-239

Wasylikowa K, Schild R, Wendorf F, Królik H, Kubiak-Martens L, Harlan JR (1995) Archaeobotany of the Early Neolithic site E75-6 at Nabta Playa, Western Desert, South Egypt. Acta Palaeobot 35:133-155 
Wasylikowa K, Dahlberg J (1999) Sorghum in the economy of the early Neolithic nomadic tribes. In: Van der Veen M (ed) The exploitation of plant resources in ancient Africa. Kluwer, New York, pp 11-31

Willcox G, Fornite S (1999) Impressions of wild cereal chaff in pisé from the 10th Millennium uncal. B.P. at Jerf el Ahmar and Mureybet: Northern Syria. Veget Hist Archaeobot 8:21-24

Wu Z, Raven PH (eds) (2007) Flora of China, vol 22. Poaceae, Missouri Botanical Garden Press, St Louis
Zhao Z (2004) Tanxun Zhongguo beifang hanzuo nongye qiyuan de xin xiansuo (Searching for the origin of dry land farming in North China, in Chinese). Zhongguo Wenwubao (Paper of Cultural Relics) 12 Oct 2004, Beijing

Zhao Z (2005) Zhiwu kaoguxue jiqi xin jinzhan (Archaeobotany and its recent progress, in Chinese). Kaogu (Archaeology) 454:522529

Zohary D, Hopf M (2000) Domestication of plants in the Old World, 3rd edn. Oxford University Press, Oxford 